\title{
THE CASE OF THE CHRONICLE OF RIVIUS ${ }^{*}$
}

\section{ARTÜRAS DUBONIS}

ABSTRACT. In his numerous works, in particular in Dzieje starożytne narodu litewskiego (Wilno, 1835-1841), Teodor Narbutt often referred to the Chronicle of Rivius, which he claimed to have found in Revel (Tallinn). Now the original (German) version of the Chronicle and its Polish translation are kept at the Library of the Lithuanian Academy of Sciences. According to Narbutt, the Chronicle, which is to be dated back to 1697, contains fragments of Rotundus' Lithuanian history, lost long ago. Rotundus, in his turn, must have possessed an analogue close to the Chronicle of Bychowiec, possibly based on the annals of a certain Pinsk monk Mitrofan. Unfortunately, the most important part of the Chronicle was lost in a fire in Narbutt's house. Due to many inconsistencies in the presentation of the biography of Rivius, fanciful descriptions of historical events, factual and chronological fallacies and drawings of various fictitious artefacts, allegedly related to the history of Lithuania, investigators have been treating the Chronicle of Rivius as a forgery initiated or produced by Narbutt. Without dismissing the Chronicle outright, though seriously doubting its authenticity as a historical record, the author of this article calls for a more thorough critical research of its provenance.

In several volumes of his Dzieje starożytne narodu litewskiego (History of the Lithuanian Nation) (hereafter referred to as the DS) and a little earlier in the Vilnius press, Teodor Narbutt often published new information on Lithuanian history, in his words, from the Chronicle of Rivius / J. F. R. ${ }^{1}$ The historian claimed to have found in it a

*I am grateful to Rūta Čapaitè and Rimvydas Petrauskas for their help in translating the German texts.

${ }^{1}$ On the ancient Jupiter temple of Vilnius, see Tygodnik Wileniski, t. 3, Nr. 60 (1817), pp. 103-107; on Władisław Vasa's painter Dankers, see ibid., Nr. 68, pp. 226-229; on the Lithuanian ancient trade, see ibid., Nr. 77, pp. 369-372. T. Narbutt, Dzieje starożytne narodu litewskiego, t. 1 (Wilno, 1835), pp. 206-207, 226, 283, 375-377; ibid. t. 3 (Wilno, 1838), p. 301 (note 1), 322, 515, 595-596, at the end of the volume there are two genealogical tables of Lithuanian dukes; ibid., t. 4 (Wilno, 1838), pp. 23 (note 2), pp. 211-212; ibid, t. 7 (Wilno, 1840), pp. 134-135; ibid., t. 9 (Wilno, 1841), appendix X, pp. 27-28. 
number of inscriptions from the long-ago lost Lithuanian history written by Augustus Rotundus Mieleski (Augustinas Rotundas). The information about the loss of the above-mentioned historical source allegedly was not exact. While publishing data from Rivius' work Narbutt imparted that he had happened to purchase the Chronicle in Revel (Tallinn) in 1808. ${ }^{2}$ It could be dated back to 1697 and the thirties of the eighteenth century. The greater part of the Chronicle, which in Narbutt's opinion contained particularly important information on the history of Lithuania, was translated into Polish and prepared for publication by him at the beginning of 1842 . It was intended as the second volume of a collection of sources of Lithuanian history. ${ }^{3}$ However, the work was not published.

At present the Chronicle of Rivius / J. F. R. (henceforth sometimes referred to as 'the original') and its Polish translation are kept in the Manuscript Department of the Library of the Lithuanian Academy of Sciences. ${ }^{4}$ The provenance inscription on the inside of the hard cover bears evidence that at the end of the nineteenth century the Chronicle was held in the Main Archive of Old Acts in Warsaw (Archiwum Główne Akt Dawnych). Some time later it was stored in the Wróblewski Library (at present the Library of the Lithuanian Academy of Sciences). The Chronicle was described at the beginning of 1950, and Narbutt's translation was described in 1947. The original was bound in dark brown calf-leather covers which were typical of the seventeenth century. State emblem watermarks of the 'naleńcz' type on page 18 and of the 'allamoda' type on some other pages can be traced. The first type was used in Lithuania in the last quarter of the seventeenth century, and the second between 1655 and $1781^{5}$

Narbutt carried out the initial study of the Chronicle. He found out that it abounded in unique unknown fragments from the lost Lithuanian history written by the Vilnius city prefect (Lith. vaitas, Pol. wójt) A. Rotundus. Therefore he argued that Rotundus had possessed a more exhaustive manuscript of the Chronicle of Bychowiec than the

${ }^{2}$ Tygodnik Wileński, t. 3, Nr. 60, p. 107; Narbutt, Dzieje, t. 1, s. 376-377 (note 3).

${ }^{3}$ Laiškai Teodorui Narbutui, parenge R. Griškaitė / Simono Daukanto raštai, (Vilnius, 1996), pp. 72-73.

${ }^{4}$ The original (German) version of the Chronicle of Rivius, Manuscript, LMAB RS, F 9-3156; Polish translation by T. Narbutt Kronika niemiecka J. F. R. LMAB RS, F 22-54.

${ }^{5}$ E. Laucevičius, Popierius Lietuvoje XV-XVIII a. (Vilnius, 1967), pp. 122, 108-109. 
one used by Maciej Stryjkowski. ${ }^{6}$ The Chronicle of Rivius also mentioned a certain monk Mitrofan of Pinsk. Narbutt supposed him to be the author of an unknown Russian chronicle which was used by Rotundus and the compiler of the J. F. R. Chronicle. This conclusion, repeated in Narbutt's works more than once, remained rather obscure: had both authors used Mitrofan's chronicle independently? Or did Rotundus make use of Mitrofan, and Rivius, of Rotundus?

Narbutt kept that unique chronicle in the library of his Szawry (Šiauriai) estate (now in Belarus, near Radun). On 12 April 1838 a fire in the manor house damaged the Chronicle and destroyed the pages with many inscriptions from Rotundus' history and two genealogical tables. However, the original of the Chronicle shows not a single singed edge or any other traces which usually abound in books damaged by fire. Narbutt even got confused giving an account about how the pages with the fragments of the Rotundus history in the Chronicle of Rivius were lost. In the pages sewn to the original he wrote that a number of pages at the end of the original had been lost during the fire of 12 April 1838 in his Szawry house when the library was plundered. ${ }^{8}$ However, in his translation prepared for the publication he already clearly indicated that the fire had destroyed three pages (at the end of the Chronicle), containing fragments from Rotundus' history, and gladly noted that those fragments had survived in his printed works. ${ }^{9}$

So, the original source of many unique facts of Lithuanian history had, nevertheless, been lost (burnt down?). This aroused our first doubts as to whether the original fragments of Rotundus' history in the so-called Chronicle of Rivius (J. F. R.) had ever existed at all. Scholars have long ago noticed that there were no original manuscripts of the unique chronicles and other sources referred to by Narbutt. Therefore, it was commonly admitted that Narbutt was a forger - a supplier of imaginary sources. ${ }^{10}$

Publishing the first materials from the Chronicle of Rivius, Narbutt indicated its author by a three-letter pseudonym (J. F. R.), fashionable at that time - Kronika niemiecka J. F. R. Some hints in the text delicately suggested the interpretation of the last letter as the

${ }^{6}$ T. Narbutt, Dzieje, t. 3, p. 301 (note 1).

${ }^{7}$ Tygodnik Wileński, t. 3, Nr. 60, p. 106; ibid., Nr. 77, p. 372.

${ }^{8}$ The German version of the Chronicle of Rivius, LMAB RS, F 9-3156, fol. 86.

${ }^{9}$ Kronika niemiecka J. F. R., LMAB RS, F 22-54, fol. 52v.

${ }^{10} \mathrm{~K}$. Chodynicki, 'Ze studjów nad dziejopisarstwem rusko-litewskiem', Ateneum Wilénskie, t. 3 (10-11) (1926), pp. 388-389. 
initial of Rotundus. ${ }^{11}$ It was perceived in that way by an anonymous reviewer ${ }^{12}$ of the first volume of Narbutt's history in 1835 (Reda Griškaite supposes that the reviewer was Michał Baliński ${ }^{13}$ ).

Some time later Narbutt himself deciphered the pseudonym: Jan Fryderyk Rivius. In the first volume of his DS Narbutt gave some biographical facts of Jan Fryderyk Rivius: he was the son (my emphasis) of the famous Johann Rivius; the father had lived in Lithuania for a long time and for this reason possessed old chronicles. ${ }^{14}$ For more exhaustive information about Riviuses, Narbutt referred researchers to Recke and Napiersky's dictionary. ${ }^{15}$ However, that dictionary provided only the information about Johann Rivius. He was born in Annaberg near Meissen in 1528, worked as a teacher in Leipzig where he became acquainted with the physician Simonus Simonius. The latter became Stefan Bathory's (the Polish and Lithuanian sovereign who reigned in 1576-1586) physician. He recommended Johann Rivius to Jan Hlebowicz (palatine of Trakai) as a teacher for his children. When Rivius became famous in Lithuania he was invited by the duke of Courland Gothard Kettler. He taught Kettler's children for nine years and won the duke widow's favour (her husband died in 1587). A few years after Kettler's death (soon after 1589 but not in 1594 as was previously believed, emphasized the Lexikon compilers), Rivius became rector of the Dome Cathedral School in Riga, and some time later - inspector of city schools. He died in 1596.

However, we could not find a slightest hint about the pedagogue J. F. Rivius' son. The biographical information became particularly confused after Narbutt's observations about the two enlightened persons in the translation and original of the Chronicle of Rivius prepared for publication in 1842. In it J. F. Rivius presented Johann Rivius as his grandfather (my emphasis) Rivius de Rive. ${ }^{16}$ It was

${ }^{11}$ Tygodnik Wileński, t. 3, Nr. 77, p. 370; the author under the pen name of 'P. S. F. Ż.' of a story by Adam Mickiewicz led S. Daukantas into error. He mistook it for the text prepared by Narbutt. Cf. V. Merkys, Simonas Daukantas (Vilnius, 1991), p. 57.

${ }^{12}$ Wizerunki i roztrzqsania naukowe, t. 12 (Wilno, 1835), p.104.

${ }^{13}$ R. Griškaitè, 'Komentarai pirmajam LTI tomui', Teodoras Narbutt, Lietuviu tautos istorija, t. 2(Vilnius, 1995), p. 441.

${ }^{14}$ Narbutt, Dzieje, t. 1, pp. 376-377 (note 3).

${ }^{15}$ J. F. v. Recke, K. E. Napiersky, Allgemeines Schriftsteller-und GelehrtenLexikon der Provinzen Livland, Esthland und Kurland, Bd. 3 (Mitau, 1831), S. 553.

${ }^{16}$ The German version of the Chronicle of Rivius, LMAB RS, F 9-3156, fol. 86v-87; Kronika niemiecka J. F. R., LMAB RS, F 22-54, fol. 53. The biographical information contained in the pages was lost in the fire. Narbutt had preserved them in a letter addressed to Napiersky. Cf. the German version of the Chronicle, fol. 86v. 
easy to establish the dates of life of the Chronicle author - 1673$1730 / 35 .{ }^{17}$ These dates could disarm any investigator of genealogy. The son was born 77 years after his father's death - this is utter nonsense. The gap between generations cannot be 'patched up' either by an assumption that they were grandfather and grandson (e.g., Jogaila's first grandson Władisław was born in 1456, i.e., twenty two years after grandfather's death). Consequently, J. F. Rivius might have been great-grandson to Johann. The author of the $D S$, however, wrote about a son or grandson.

Further inspection revealed more inaccuracies and even irreconcilable contradictions. Presenting the information from his precursor's biography J. F. Rivius repeated an inaccuracy found in the Lexikon, namely that Johann Rivius was a teacher of the Trakai palatine (my emphasis) Jan Hlebowicz's children. ${ }^{18}$ According to the author some time later his father (or grandfather?) abandoned the teaching profession and left Lithuania in 1585. However, Hlebowicz became palatine of Trakai only on 1 June 1586, previously having occupied a respectable position of the castellan of Trakai. In fact, Rivius had to teach the children of Hlebowicz who was a land treasurer and a chancery secretary of the sovereign. ${ }^{19}$ The dating arithmetic used by Rivius (Narbutt?) is rather simple: in 1585 Johann Rivius departed from Lithuania, plus nine years of teaching in Kettler's service and we get the year 1594 when J. Rivius became a school director in Riga. However, the dates of J. Rivius' career given by Recke and Napiersky are quite different. They clearly indicated in their Lexikon that J. Rivius (J. F. Rivius' father or grandfather) became a rector in about 1589. Consequently, he began teaching the duke of Courland's children in 1580. Thus, he had to leave Lithuania not in 1585 , as was stated by J. F. Rivius, but in the late 1570 s. Where did the misleading year 1594, criticized by Lexicon compilers, come from? That date, taken by J. F. Rivius as the beginning of his father's (or grandfather's) work and travels, appeared as genuine and reliable in Friedrich Konrad Gadebusch's bibliography. ${ }^{20}$ It contained a phrase from Rivius' biography almost word for word repeated in volume one of Narbutt's history: 'Johann Rivius' father was the famous Johann

${ }^{17}$ Kronika niemiecka J. F. R., LMAB RS, F 22-54, fol. $18,53-53 v$; the German version of the Chronicle, LMAB RS, F 9-3156, fol. 62v, 87v.

${ }^{18}$ Kronika niemiecka J. F. R., LMAB RS, F 22-54, fol. 2-2v, 53; The German version of the Chronicle, LMAB RS, F 9-3156, fol. 86v.

${ }^{19} \mathrm{~J}$. Wolff, Senatorowie i dygnitarze Wielkiego Księstwa Litewskiego 1386 1795 (Kraków, 1885), pp. 59, 65, 110, 186.

${ }^{20}$ F. K. Gadebusch, Livländische Bibliothek, T. 3 (Riga, 1777), S. 38-39. 
Rivius'. ${ }^{21}$ Alas, the famous one was from Annaberg, whereas his son was the aforementioned teacher J. Rivius. In our opinion, some of the biographical information given about Rivius by Gadebusch was 'creatively' elaborated in the Chronicle of J. F. R. For instance, referring to some eighteenth-century researchers, Gadebusch cautiously hinted that Johann Rivius had been mentioned as one of the participants of the Calendar uprising in Riga in 1585, though that fact was not supported by other important sources. ${ }^{22}$ In that year the predominantly German Lutheran nobility of Riga, exploiting the believers' discontent with the forcible introduction of the Gregorian calendar in Livonia, directed the uprising against the Jesuits and the Lithuanian-Polish administration of the region. J. F. Rivius himself indicated the date of his birth in the Chronicle in both styles. In that way he suggested to a more attentive reader that hostility towards the new and love for the old style had been a tradition in the Rivius family. ${ }^{23}$ Gadebusch also narrated that after 1580 Rivius, a Lutheran, was a king of Poland's preacher and by his suggestive preaching helped the dispirited Vilnius Protestants to understand Christ's mystery during the Last Supper. ${ }^{24}$ In the Chronicle that fact was transformed and developed: the results of Jesuit activity against Rivius were made evident. According to J. F. R. version his father (perhaps grandfather) had to leave Lithuania a year before Stefan Bathory's death as a result of Jesuit intrigues. He left Lithuania for Prussia. ${ }^{25}$ The origin of this information is absolutely obscure, because only the fact of a 'direct' way from Hlebowicz to Kettler's estate is known. There is no evidence suggesting Johann Rivius' stay in Prussia.

Summing up the biographical information about J. F. Rivius, it must be said that the difference of the treatment of his relationship with Johann Rivius in the Narbutt history and in the Chronicle is obvious. What was he, after all, to the famous pedagogue: son or grandson? J. F. Rivius did not offer any definite original evidence about his father (grandfather) which would have been new to Recke and

${ }^{21}$ Ibid., p. 37:' Johann Rivius ... Sein Vater, der bekannte Johann Rivius...'; T. Narbutt, Dzieje, t. 1, s. 376 (note 3): '... autorem tego pisma był Jan Fryderyk Rivius, syn znakomitego Jana Rivius' (in both cases the emphasis is mine).

${ }^{22}$ F. K. Gadebusch, ibid., p. 39.

${ }^{23}$ The German version of the Chronicle of Rivius, LMAB RS, F 9-3156, fol. $22 \mathrm{v}$ (§ 69); Kronika niemiecka J. F. R., LMAB RS, F 22-54, fol. 18. The date of birth is 9 April, old style, and 30 March, new style, 1673.

${ }^{24}$ F. K. Gadebusch, ibid., p. 38.

${ }^{25}$ Kronika niemiecka J. F. R., LMAB RS, F 22-54, fol. 53; the German version of the Chronicle of Rivius, LMAB RS, F 9-3156, fol. 86v-87. 
Napiersky or Narbutt. In other words, J. F. Rivius knew about his father no more than Recke and Napiersky, Gadebusch and Narbutt. The author of the Chronicle repeated all professional and chronological errors made by the above-mentioned scholars. The additional, somewhat more original, information from Johann Rivius' past was derived and transformed from real and doubtful facts contained only in printed works. The Prussian period of J. Rivius is artificial and does not stand up to elementary criticism. J. F. Rivius himself is not mentioned in any bibliography or lexicon, ${ }^{26}$ except in Narbutt's work. Narbutt is the only who found the birth (1673) and death (1730-35) dates indicated by the author in his Chronicle. Only from the Chronicle did he learn that in 1689 J. F. R. left Königsberg (sic) and went to Courland where he worked as a pastor. ${ }^{27}$

All professional mistakes, chronological and genealogical contradictions are due to the fact that J. F. Rivius had never existed - he was an 'invented' author. His image was created on the basis of at least two Livonian biographical and bibliographical lexicons using the evidence relating to two or three persons. In Narbutt's words, the full name of Rivius' father or grandfather was Johann Rivius de Rive. Recke and Napiersky's Lexikon contained two pages of information where along with the names of two Johanns Riviuses there was also Matthias Rives. Thus, a part of the name of the famous teacher de Rive could be formed from the last name of the Tartu university student of the seventeenth century. J. F. R. was easily derived from Johann Rivius adding the second name Friedrich. Where could this name come from? The sources were numerous: Friedrich Konrad Gadebusch, whereas from Johann Friedrich von Recke even J. F. R. could be derived. Narbutt had a cousin whose name was Fryderyk. It

${ }^{26}$ Attempts are made to prove that Johannes Fridericus Ruvius, Wendensis enrolled at the University of Dorpat (Tartu) in 1690 was the author of the Chronicle under study. Cf. Э. Гячяускас, 'Тартуский университет в XVII и Литва', Тартуский государственный университет: история развития, подготовка кадров, научные исследования, 1 / Общественные науки (Тарту, 1982), с. 60. However, he could not be the same person. In Narbutt's version the author came to Courland from Königsberg (Prussia). That student was from Wenden (Cēsis). The spellings of the names differ, too. According to E. Gečiauskas, the author's name in the Chronicle of Rivius ( $\$ 117$ ) is spelled Rüviss. Actually the name is Kürche. See, The German version of the Chronicle, LMAB RS, F 9-3156, fol. 42; and cf. Kronika niemiecka J. F. R., LMAB RS, F 22-54, fol. 26v. The variant form Rüviss is not to be found. It would also be surprising that J. F. R. did not boast of his higher education, i.e., he himself 'did not know' about his own studies at the University of Tartu.

${ }^{27}$ Kronika niemiecka J. F. R., LMAB RS, F 22-54, fol. 53. 
is interesting to note that in 1808-1809 Narbutt, as an officer of the Russian army, participated in the Finnish war and visited Estonia where he got acquainted with the man of letters August Friedrich (my emphasis) Kotzebue. In R. Griškaitè's opinion, this acquaintance might have been the most impressive episode in Narbutt's young days. ${ }^{28}$ The author of the Chronicle of J. F. R. might have been 'invented' between 1817 (the date of the first mention of that Chronicle in the Vilnius press) and 1842 (when the Chronicle was prepared for publication by Narbutt). All these circumstances allow us to assume that this work was done in Narbutt's 'scientific kitchen'. He was the only who possessed the Chronicle. None of the contemporaries who had contacts with Narbutt had ever seen the Chronicle with their own eyes. Narbutt was aware of the above-cited biographical bibliographies and repeated their errors. He got confused stating that J. F. R. was J. Rivius' son (my emphasis) and later, while preparing the second edition of the $D S$ for the publication, he tacitly replaced 'son' (without any special comments) by a chronologically more reliable 'grandson'.29

There is one more subtle circumstance which proves that J. F. Rivius's biography was invented by Narbutt himself. In his letter of 11 April 1833, F. K. Napiersky answered a few questions put by the Szawry estate historian. Narbutt evidently asked for some information about Rivius, an Erdwallen (Courland) pastor of the eighteenth century. Napiersky wrote that he had no information about pastor Rivius from Courland of that time. He only knew about Master Grott who had been a pastor in Erdwallen in 1706 and in the same year had been transferred to Libau (Liepāja). ${ }^{30}$ In his Chronicle, J. F. R. repeated this information as facts of his own biography, i.e., he alledgedly worked as a pastor in Erdwallen from October of 1706 in the place of Master Grott who had moved to Libau. ${ }^{31}$ Narbutt seems not to have known anything about Master Grott until 1833. But that could not be true because Rivius had mentioned him in his Chronicle, 'written' long ago before 1833 (Narbutt obtained it in 1808 and started to publish some excerpts from it in 1817). Thus, the legend of Rivius' biography must have been created between 1833 and 1842 .

${ }^{28} \mathrm{R}$. Griškaite, 'Komentarai pirmajam LTI tomui', Teodoras Narbutt, Lietuviu tautos istorija, t. 2, p. 457, note 16.

${ }^{29}$ Ibid., pp. 497-498 (comment note 170). See above, note 14.

${ }^{30}$ Napiersky's letters to Narbutt, LMAB RS, F 18-185/4, fol. 143.

${ }^{31}$ The German version of the Chronicle, LMAB RS, F 9-3156, fol. 87v and $\S 135$ (here J. F. R. himself presented the facts of his biography). 
Johann Friedrich Rivius never existed; he and his biography were invented. Nevertheless, the manuscript of his imaginary chronicle is vigilantly safeguarded in the Manuscript Department of the Library of the Lithuanian Academy of Sciences.

The so-called Chronicle of Rivius is written in German, some inscriptions are in Latin, and there are even Latvian words in it. The Chronicle abounds in various records, notes and remarks. We learn that the Livonian Master Friedrich Finke built Bauska castle in 1442; in 1510 the Riga militia presented a chandelier to the Dome Cathedral; in 1717 Turks made an assault on Belgrade; in the years of famine a Lithuanian woman roasted her dead unbaptized babies and ate them; in 1276 one 42 -year old countess gave birth to 364 babies. There is no sense in trying to find the sources of such information or determine its reliability. On the other hand, the manuscript is an original though we would not dare to date it, for instance, to the eighteenth century. Perhaps it was written in the second half of the seventeenth century. Narbutt defined the Chronicle as an encyclopedic compilation. In Rimantas Jasas' opinion, this work should be attributed to the silva rerum type. ${ }^{32}$ 'Unique' materials of Lithuanian history glitter in these ashes. Narbutt extensively used them in his works. Some of them might have been taken from A. Rotundus' history. Their examples are: Lithuanian and Samogitian golden coins from the thirteenth century (sic), a statuette of a Lithuanian god, a Lithuanian pagan standard with a cock on the tip of the pole, an inscription on the king Mindaugas tombstone, a description of the Perkūnas shrine in Vilnius, an note about a certain Milesius (of course, Rotundus) chronicle which was lost in a Vilnius fire, etc. ${ }^{33}$ Narbutt regretted that many fragments of the Rotundus history had burnt down in the Szawry estate.

${ }^{32} \mathrm{R}$. Jasas kindly conveyed this idea to the author at the conference devoted to Maciej Stryjkowski held in Vilnius on 24-25 April 1997.

${ }^{33}$ The German version of the Chronicle, LMAB RS, F 9-3156, fol. 18: 'a statuette of a god', cf. T. Narbutt, Dzieje, t. 1, table II, pict. 5); 'a standard' - one with the 'Gediminid Columns', the other black and white with a cock-shaped staff-head; cf. Kronika niemiecka J. F. R., LMAB RS, F 22-54, fol. 14v); fol. 30: 'an old Samogitian coin' cf. T. Narbutt, Dzieje, t. 1, table III, pict. 12; fol. 34v: 'an old Samogitian golden coin' cf. T. Narbutt, Dzieje, t. 1, table III, pict. 15; fol. 33v: 'Mindaugas and his wife visit the Pope in Rome'; fol. 41v: 'the inscription on Mindaugas' tombstone in Aglona'; fol. 43: ' a certain Milesius' manuscript is burnt in the Vilnius fire in 1610'; fol. 51: 'the Perkūnas shrine in Vilnius - today that site is occupied by St. Stanisław's Church'; fol. 61: 'a pagan emblem' cf. T. Narbutt, Dzieje, t. 1, table IV, pict. 24, identical to a water-mark 'bull's head with a cross between the horns'. 
A deeper insight into the Chronicle of Rivius revealed a possibility to determine the origin of some presented evidence quite accurately. In volume 4 of his history, Narbutt described king Mindaugas' journey to Rome to the Pope Urbanus IV as a very reliable fact. According to Narbutt, the Lithuanian sovereign allegedly chose that way to salve his conscience for his apostasy and for his irresistable desire to make offerings to pagan gods. ${ }^{34}$ However, according to the Chronicle of Rivius, Mindaugas and his wife accompanied by the Master of Livonia, Andreas von Stirland, travelled to Rome in 1254 to discuss with the Holy Father the matters related to the crown for Lithuania. ${ }^{35}$ In his comments to the translation of the Chronicle, Narbutt openly expressed his pleasure and surprise that he had managed to find a proof of Mindaugas' journey to Rome and speculated about the origin of that information: human memory, tradition, some lost written record? ${ }^{36}$ But which of the two descriptions of journey of Mindaugas to Rome is more correct: that of the DS or of the Chronicle? Both are false. The Rhymed Chronicle of Livonia (Livländische Reimchronik of the end of the thirteenth century) describes the mission of Lithuanian neophytes sent by Mindaugas to the Pope. The mission was headed by the Lithuanian nobleman Parbus. ${ }^{37}$ The genuine fact is altered, resulting in two absolutely different information items suspiciously united by Narbutt's ambitious assessment about the journey of Mindaugas to Rome. The confusion is the same as in the case of the relationship between Johann Rivius and Johann Friedrich Rivius. Similar observations can be made with regard to the inscription on the Mindaugas tombstone. The $D S$ indicates the year 1263 as the date of the death of Mindaugas, the Chronicle $-1280 .{ }^{38}$ If the original source is the same - the Chronicle of J. F. R. - why does then information vary? Another fact of doubtful value is Narbutt's communication in volume 3 of the $D S$ about the settling of merchants in the Daugava estuary area in 1111 rather than in 1158 as is known from historical scholarship. According to the Chronicle of Rivius (Rotundus), the merchants came from Lübeck, not from Bremen. ${ }^{39}$ It would be a

${ }^{34}$ T. Narbutt, Dzieje, t. 1, s. 211.

${ }^{35}$ The German version of the Chronicle, LMAB RS, F 9-3156, fol. 33v.

${ }^{36}$ Kronika niemiecka J. F. R., LMAB RS, F 22-54, fol. 20-20v.

${ }^{37}$ E. Gudavičius, Kryžiaus karai Pabaltijyje ir Lietuva XIII amžiuje (Vilnius, 1989), p. 102.

${ }^{38}$ T. Narbutt, Dzieje, t. 1, s. 375-376, table V, pict. 38; The German version of the Chronicle, LMAB RS, F 9-3156, fol. 41v.

${ }^{39}$ 'About the Lithuanian ancient trade', Tygodnik Wileński, t. 3, Nr. 77, pp. 369-372; T. Narbutt, Dzieje, t. 3, pp. 322-323, 595-596. 
futile task to try to look out for this inscription in the original of the Chronicle. It seems likely that that information was contained in the three pages of the historical source burnt down in Szawry. Meanwhile this information and date are obviously transformed using the material of the Chronicle of Stryjkowski. Ignacy Daniłowicz, in 1840 summarizing the information about the then available chronicles of Lithuania, described one from Livonia. Jan Jeronim Chodkiewicz allowed Stryjkowski to make use of it. It was a parchment manuscript from the church of the Rumbor castle with the materials of the thirteenth and fourteenth centuries of Lithuanian history. In Stryjkowski's work it began in the following way: 'Roku Pańskiego 1111 począł się zakon w Liflanciech Braciey Domu Niemieckiego' ${ }^{40}$ (In the year of our Lord 1111 was established the Order of the Livonian Brethren of the German House). Daniłowicz corrected the year into 1211 because namely in that year the emperor approved the regulations of the Livonian Brethren. Therefore the year 1111 in Stryjkowski's work should be interpreted as a kind of proof-reader's mistake. Whereas, in Narbutt's works this communication was transformed and treated as a fragment of the Rotundus history which miraculously survived in the work of the imaginary Rivius. It is quite an easy task to reveal the source of Rivius' description of the Vilnius fire in 1610. According to Rivius an Evangelical church outside the city wall was on fire. The fire destroyed the congregation library including the Chronicle of Milesius that was particularly emphasized. ${ }^{41}$ The genuine information about the fire is available in volume 1 of the history of Vilnius published by Ignacy Kraszewski in 1840. It was he who described the Vilnius fire of 1610 during which three Reformation churches were burnt down. The fire started in the Catholic church of St. Stephen outside the city wall. ${ }^{42}$ The Chronicle of Rivius made use of the date (1610) in Kraszewski's work. ${ }^{43}$ It was mercilessly mixed with the information about the fire outside the city wall and with the well known fact that the Evangelical church stood outside the city wall. But it appeared

${ }^{40} \mathrm{M}$. Stryjkowski, ... Kronika polska, litewska, żmódzka i wszystkiej Rusi ...(Królewiec, 1582), s. 323; I. Daniłowicz, 'O kronikach litewskich', Magazyn powszechny, t. 7 (Warszawa, 1840), s. 181.

${ }^{41}$ The German version of the Chronicle, LMAB RS, F 9-3156, fol. 43: 'a manuscript of a certain Milesius burns up in the Vilnius fire in 1610.'

${ }^{42}$ I. Kraszewski, Wilno od początków jego do roku 1750, t. 1 (Wilno, 1840), s. 413 (notes 40-42).

${ }^{43}$ The Evangelical church is burnt down in the Vilnius fire in July, 1611, cf. H. Merczyng, 'Czterokrotne zburzenie Zboru', Zarys historyczny Wileńskiego kośc. ew.-ref. i jego biblioteki (Wilno, 1932), s. 25-26. 
there only in 1640 after a decision of the Seimas of the Republic. ${ }^{44} \mathrm{~A}$ total chaos of facts.

We suspect that the Chronicle of Rivius is a forgery. It was produced on the basis of an original manuscript of the second half of the seventeenth century having been supplemented with 'Lithuanian' information, attributed to Rotundus. Some insertions in the 'Rotundus' history were made in a different handwriting. Or, perhaps, it was written on paper datable to the seventeenth-eighteenth centuries imitating a specimen of some original manuscript. We suppose that Narbutt participated in its 'production'. Instead of categorical accusations we are going to offer some suggestions as to further investigations and some speculations. The same materials in the Chronicle of Rivius and in Narbutt's $D S$ are often treated differently. These mistakes could have occured because, at the time when Narbutt was writing his history, the text of the Chronicle had not yet been completed with the exception of some pieces which were published in the Vilnius press and afterwards introduced into the DS. This supposition is indirectly supported by the fact that while citing the Chronicle Narbutt would never indicate the pages of the manuscript. In the 'original', however, they are precisely numbered. In the DS Narbutt conscientiously indicated the pages of the Chronicle of Bychowiec - this version of the Lithuanian chronicle does exist. Perhaps, the confusion occurred while making attempts to hide the real sources of the Chronicle, which might have been written by another person on the initiative of Narbutt.

Why did Narbutt need an artificial source of Lithuanian history? It presented for him an opportunity to legalize two very important pieces of information: the evidence about Mindaugas' father Ringaudas (from the 'burnt-down' genealogical table in the Chronicle of Rivius) and good news to Lithuanian historians about the miraculously surviving unique fragments of the Rotundus history of Lithuania. However, Prof. Ignacy Daniłowicz strictly refused to believe in the discoveries of Narbutt. ${ }^{45}$ In his Vilnius history Kraszewski published the information from the Chronicle about a pagan shrine in Vilnius. He did it doubting their reliability, but pointing out that it would

${ }^{44}$ Ibid., s. 28-29; I. Kraszewski, Wilno od poczqtków (Wilno, 1840), t. 2, s. 20-21.

${ }^{45}$ I. Daniłowicz, 'Wiadomość o właściwych litewskich latopisach', Ateneum, t. 6 (Wilno, 1841), s. 44. He asserts that it is impossible to prove that the Pinsk monk Mitrofan is referred to as the author of Bychowiec chronicle (in the Chronicle of Rotundus). Nobody has ever seen or heard about any Rotundus history. Compare Narbutt's opinion on this question, Narbutt, Dzieje ..., t. 3, s. 578-582. 
be unfair not to mention that source. ${ }^{46}$ Baliński (in his review of volume 1 of Narbutt's history in 1835) urged the author to publish as soon as possible the unique chronicle if it existed at all. ${ }^{47}$ At the same time he gently hinted about the irresistable desire of Narbutt to discover new facts of the history of Lithuania which were not supported by any sources. ${ }^{48}$ In 1833 Narbutt informed Napiersky about the Chronicle of Rivius. As has already been mentioned Napiersky had no information about J. F. Rivius. ${ }^{49}$

Already some time ago a few regularities characteristic of Narbutt's falsifications were observed. We have mentioned Chodynicki's remark that the falsifications lacked the support of original manuscripts. They always abounded in irreconcilable chronological discrepancies. ${ }^{50}$ Older and rarer publications were taken as sources of dates and facts. ${ }^{51}$ The authors of Narbutt's falsifications are represented by imaginary or long ago dead persons. ${ }^{52}$

In the times of flourishing Romanticism in Eastern Europe the falsified sources of the history of nations and states were commonplace and widespread phenomena. They represented attempts to raise the national pride and disassociate oneself from the cultural influence of other nations. ${ }^{53}$ In 1817-1819 Vaclav Hanka 'discovered' the Kraledvorska and Zelenogorska Chronicles relating to the history of the Czech nation. Only at the end of the nineteenth century they were

${ }^{46}$ I. Kraszewski, Wilno od poczq̨tków, t. 2, 183-187.

${ }^{47}$ Wizerunki i roztrzqsania naukowe, t. 12, s. 104 (about the author, cf. note 13).

${ }^{48}$ Ibid., p. 109.

${ }^{49}$ K. E. Napiersky's letters to T. Narbutt, LMAB RS, F 18-185/4, fol. 143. He confessed that he had no knowledge about the pastor I. I. Rivius of Erwalle (Courland) (sic not about J. F. Rivius) but only about the Dobele pastor Rivius mentioned in 1587 (cf. note 30).

${ }^{50}$ In the 'Rawdański' Chronicle (of Raudonè), Chodynicki mentions the confused dates of the reign of duke Alexander (ruled between 1492 and 1506), see Chodynicki, ibid., p. 389; while investigating the falsified description of the Vilnius city wall H. Łowmiański emphasized the confusion of the dates, cf. H. Łowmiański, 'Sfalszowany opis obwarowania m. Wilna', Ateneum Wileńskie, t. 3 (9), s. 85.

${ }^{51}$ Ibid., p. 90-91. It contains the information about a poor study by Grzybowski, OFM, on the history of the Franciscan Order in Lithuania published in 1740. Narbutt obviously used the factual material from this study.

${ }^{52}$ Ibid., pp. 93-94.

${ }^{53}$ Освободительные движения народов Австрийской империи: возникновение и развитие (конеи XVIII в. - 1849) (Москва, 1980), с. 172, 212. 
proved to be forgeries. The final conclusions were drawn only after a special expertise in 1968-1969. ${ }^{54}$ Thus, the case of the Chronicle of Rivius is yet to be subjected to a critical examination, too.

\section{Author Details}

Artūras Dubonis is Head of the Department of Archaeography, Lithuanian Institute of History. His special interests are in the sources of Lithuanian history of the 15th and 16th centuries, and especially the Lithuanian Metrica. He has published a monograph on the state structure of mediaeval Lithuania and several scores of articles on social, economic issues and foreign policy of Lithuania.

Address: Department of Archaeography, Lietuvos istorijos institutas, Kražių 5, LT-2001 Vilnius, Lithuania

Email: history@takas.lt

\section{RIVIJAUS KRONIKOS ISTORIJA}

Santrauka

\section{ARTÜRAS DUBONIS}

Daugelyje savo darbu (ir ypač Dzieje starożytne narodu litewskiego, Wilno, 1835-1841) Teodoras Narbutas dažnai rèmési Rivijaus Kronika(J.F. R.), kuriąjis teige radęs Revelyje (Taline). Dabar jos vokiškas originalas ir lenkiškas vertimas saugomas Lietuvos Mokslų akademijos bibliotekoje. T. Narbuto tvirtinimu, $1697 \mathrm{~m}$. datuotinoje kronikoje yra fragmentų iš seniai dingusios Rotundo Lietuvos istorijos. Rotundas, savo ruožtu, galèjo turèti Bychovco Kronikai artimą analogą galbūt paremtą kažkokio Pinsko vienuolio Mitrofano metraščiais. Deja, svarbiausioji Rivijaus Kronikos dalis žuvo per gaisrą T. Narbuto dvare. Dèl ịvairių nenuoseklumų pateikiant Rivijaus biografija, istorinių ¡vykių aprašymų, faktinių ir chronologinių klaidų ¡vairių fiktyvių objektų, tariamai susijusių su Lietuvos istorija, piešinių tyrinètojai laikè Rivijaus Kroniką klastote, kurią inicijavo ar net atliko pats T. Narbutas. Šio straipsnio autorius, kategoriškai neatmesdamas Kronikos ir kartu rimtai abejodamas jos kaip istorinio šaltinio autentiškumu, siūlo nuodugniai patyrinèti neaiškią šio veikalo kilmę.

Received 2 February 2000

${ }^{54}$ Чешская начия на заключительном этапе формирования: 1850 2.начало 70х годов (Москва, 1989), с. 137. 